\title{
Differential expression dynamics of Growth differentiation factor9 (GDF9) and Bone morphogenetic factor15 (BMP15) mRNA transcripts during in vitro maturation of buffalo (Bubalus bubalis) cumulus-oocyte complexes
}

\author{
Muralidharan Kathirvel $^{1 *}$, Eswari Soundian ${ }^{2}$ and Vijayarani Kumanan ${ }^{3}$
}

\begin{abstract}
The present study has evaluated the association of growth differentiation factor9 (GDF9) and bone morphogenetic protein15 (BMP15) mRNA expression in cumulus-oocyte complexes (COCs) of buffalo ovary during in vitro maturation (IVM). GDF9 and BMP15 are expressed specifically in mammalian oocytes and also participate in cumulus-oocyte crosstalk. Quantitative real-time polymerase chain reaction (qRT-PCR) technique was applied to investigate the relative abundance (RA) of GDF9 and BMP15 mRNA transcripts throughout the IVM process. Relative mRNA expression pattern of these specific genes were assessed in oocytes and cumulus cells at 0, 6, 12 and 24 h of in vitro culture. Our results revealed that RA of GDF9 during different hours of IVM showed significant reduction between $0 \mathrm{~h}$ and $24 \mathrm{~h}$ of maturation in oocytes and BMP15 transcript increased significantly $(\mathrm{P}<0.05)$ between $6 \mathrm{~h}$ and $12 \mathrm{~h}$ and decreased again between $12 \mathrm{~h}$ and 24 . In cumulus cells, GDF9 remained stable during IVM upto $12 \mathrm{~h}$ of maturation and decreased significantly between $12 \mathrm{~h}$ and $24 \mathrm{~h}$ of maturation. Conversely, significant reduction of BMP15 was observed between $0 \mathrm{~h}$ and $6 \mathrm{~h}$, stayed stable upto $12 \mathrm{~h}$ and became undetectable at $24 \mathrm{~h}$ of maturation. In conclusion, these two genes were differentially expressed during the period of oocyte maturation process and notably, BMP15 expression pattern is associated specifically with the period of cumulus cell expansion.
\end{abstract}

Keywords: BMP15, COC, Expression, GDF9, IVM

\section{Introduction}

Growth factors synthesized from mammalian oocytes popularly known as oocyte secreted factors (OSFs) play numerous role in ovarian folliculogenesis. In particular, a growing body of evidence in recent years indicated that two famous members of Transforming growth factor- $\beta$ superfamily, GDF9 and BMP15 have been involved in the control of ovulation rate in mammals (Moore et al. 2004). They act synergistically to affect development of the cumulus-oocyte complexes in mice (Yan et al. 2001). GDF9 plays critical roles in granulosa and theca cells growth, as

\footnotetext{
* Correspondence: drdaran86@gmail.com

'Department of Veterinary Physiology, Laboratory of Reproductive Physiology, Madras Veterinary College, Chennai-600 007, TANUVAS, Tamil Nadu, India

Full list of author information is available at the end of the article
}

well as in differentiation and maturation of the oocyte (Hreinsson et al. 2002). Further, the level of GDF9 in human follicular fluid has been found significantly correlated with the nuclear maturation of the oocytes and embryo quality (Gode et al. 2011). Moreover, BMP15 has also been thought to be involved in oocyte maturation and follicular development alone or along with the related protein, GDF9. Both the proteins are progressively expressed by the oocytes of growing follicles throughout folliculogenesis (Dube et al. 1998; Laitinen et al. 1998). This stage specific expression through intra-follicular cascade at the correct time is vital for follicular growth in order to reach the ovulatory phase (Campbell 2009). In this regard, the expression of GDF9 and BMP15 has been studied extensively in follicular compartment cells in the ovaries of 
various species, while poorly explored in the COCs within culture systems.

The domestic Asian water buffalo (Bubalus bubalis) is a multipurpose livestock animal. It is of particular important production animal due to the source of high quality animal protein in developing countries (Zicarelli 1994). IVM is an essential technology under assisted reproductive technologies (ARTs), which enables oocytes to achieve maturation and acquire the competence for subsequent embryonic division leading to blastocyst formation (Lonergan et al. 2003; Somfai et al. 2011). This technique is valuable not only because they allow the production of large numbers of oocytes, but also because they provide a valuable in vitro model to study the gene expression at different maturational stages of oocytes. During the maturation process, oocytes accumulate large amount of maternal mRNAs to dictate the developmental competence of oocytes (Watson 2007). Quantification of RNA developmentally important oocyte secreted factors in oocytes during maturation might be valuable when setting up IVM medium that lack the normal hormonal interplay found in vivo. Considering the importance of buffalo and the necessity of designing potent ART protocols for this species, the current study aimed for analysing expression pattern of two oogenesis specific genes during maturation. For this purpose, we used quantitative real-time PCR (qRT-PCR) technique for mRNA expression of GDF9 and BMP15 genes. Accordingly, the current work will provide important leads for understanding the mRNA transcriptional level of GDF9 and BMP15 genes in oocytes during IVM in case of buffalo.

\section{Materials and methods}

All chemicals and culture media were obtained from Sigma Chemical Co. (USA) unless otherwise stated. Disposable plastic wares used were purchased from Nunc, Denmark.

\section{Collection of cumulus oocyte complexes and IVM}

Buffalo ovaries were collected from an abattoir and transported in thermos containing pre-warmed $\left(37^{\circ} \mathrm{C}\right)$ normal saline to the laboratory within $2-3 \mathrm{~h}$. In the laboratory, ovaries were washed five times in modified Dulbecco's phosphate buffered saline (mDPBS) containing gentamicin. Oocytes were aspirated with a 10 cc syringe using 20 gauge needle into $50 \mathrm{ml}$ conical tubes from follicles $(>3 \mathrm{~mm}$ in diameter) of buffalo ovaries. The aspirated COCs were graded based on morphological appearance of the cumulus cell investments and homogeneity of ooplasm under stereo zoom microscope as described by Nandi et al. (1998) and the different grades are, Grade A (Excellent): COCs with more than 4 layers of compact cumulus cells with evenly granular homogenous ooplasm; Grade B (Good): COCs with 2-4 layers of compact cumulus cells with evenly granular homogenous ooplasm; Grade C (Poor): COCs with one layer of cumulus cells with irregular dark ooplasm; Grade D (Poor): Naked oocytes with irregular dark ooplasm. The aspirated oocytes of grade A and B alone were chosen for in vitro maturation studies. Average of 20-30 oocytes were cultured in maturation media and each experiment was replicated on eight separate occasions. From 851 ovaries, total of 749 oocytes were used for this study. Maturation medium consisted of TCM-199 supplemented with $10 \% \mathrm{FBS}, 10 \mathrm{IU} / \mathrm{ml} \mathrm{LH}, 0.5 \mu \mathrm{g} / \mathrm{ml}$ $\mathrm{FSH}, 1 \mu \mathrm{g} / \mathrm{ml}$ estradiol-17 $\beta, 100 \mathrm{IU} / \mathrm{ml}$ penicillin and $100 \mu \mathrm{g} / \mathrm{ml}$ streptomycin. The oocytes were subjected to mature in the maturation medium in $35 \times 10 \mathrm{~mm}$ petridishes for $24 \mathrm{~h}$ in a $\mathrm{CO}_{2}$ incubator maintained at $39^{\circ} \mathrm{C}$, $5 \% \mathrm{CO}_{2}$ with maximum relative humidity.

\section{Assessment of oocyte maturation}

The maturation of oocytes was evaluated under stereomicroscope based on the degree of cumulus expansion (Kobayashi et al. 1994) and further evaluated by identifying the first polar body in the perivitelline space when the oocytes were denuded after maturation. For this purpose, a proportion of COCs were recovered from the culture and transferred to $1.5 \mathrm{ml}$ tube containing $400 \mu \mathrm{l}$ of $0.1 \%$ trypsin-EDTA solution. Then vortex-agitated for $1 \mathrm{~min}$ to remove cumulus cells and thus denuded oocytes were visualised for extrusion of polar body.

\section{Collection of samples for expression analysis}

Immature oocytes $(0 \mathrm{~h})$ were treated with 0.1 per cent trypsin-EDTA for 2-3 min and mechanically denuded of surrounding cumulus cells by repeated pipetting. The cumulus-free oocytes were observed under stereo zoom microscope to ensure that they were free of cumulus cells. The oocytes were washed twice in PBS and transferred to a fresh $1.5 \mathrm{ml}$ micro centrifuge tube with minimum volume of PBS and then frozen at $-80^{\circ} \mathrm{C}$. After the removal of cumulus free oocytes, the remaining cumulus cells in PBS were transferred to micro centrifuge tube and centrifuged at $300 \mathrm{~g}$ for $2 \mathrm{~min}$ according to Caixeta et al. (2009). The supernatant was removed and the cell pellet was resuspended with minimum volume of PBS and stored at $-80^{\circ} \mathrm{C}$ for RNA isolation. During different hours of $\operatorname{IVM}(6,12$ and $24 \mathrm{~h})$, the cumulus denuded from matured oocytes were collected as mentioned above and the oocytes with evenly granular ooplasm after cumulus removal with a visible polar body in the peri-vitelline space were also stored at $-80^{\circ} \mathrm{C}$ for RNA isolation.

\section{RNA isolation and CDNA preparation}

Total RNA was extracted from pools of immature (IM 75), in vitro matured oocytes (MO 50), cumulus cells (cells removed from 50-75 COCs) using RNeasy Plus Mini Kit (Qiagen, USA) and eluted in $30 \mu \mathrm{l}$ RNase free-water. The 
Table 1 Primers used for qRT-PCR analysis

\begin{tabular}{cccc}
\hline Gene & Primer sequence $\left(\mathbf{5}^{\prime} \boldsymbol{\rightarrow} \mathbf{3}^{\prime}\right)$ & Size $(\mathbf{b p})$ & $\begin{array}{c}\text { GenBank } \\
\text { accession No. }\end{array}$ \\
\hline GDF-9 & $\begin{array}{l}\text { F: TGCTCAGGCTTTCACAGGTGGCA } \\
\text { R: GACGGGACAATCTAACACCCTCAG }\end{array}$ & 131 & FJ529501.2 \\
\hline BMP-15 & $\begin{array}{l}\text { F: TGGTGAAGCAGGCGTCAGAG } \\
\text { R: CGCCAGTAGAAGCAGGGGTGAT }\end{array}$ & 167 & EF375880.1 \\
\hline GAPDH & $\begin{array}{l}\text { F: CCTGGAGAAACCTGCCAAGTA } \\
\text { R: GGTAGAAGAGTGAGTGTCGCT }\end{array}$ & 139 & GU324291.1 \\
\hline
\end{tabular}

purity and concentration of isolated RNA was determined by ND1000 spectrophotometer (Nanodrop technologies, USA) and purity was assessed using the A260/A280 nm ratio with expected values between 1.8 and 2.0. The cDNA synthesis was carried out with $6 \mu \mathrm{l}$ of RNA using Superscript III first-strand synthesis system (Invitrogen, USA) and random hexamer primer in a final reaction volume of $25 \mu \mathrm{l}$. The cDNA synthesis reactions were carried at $25^{\circ} \mathrm{C}$ for $10 \mathrm{~min}$ for annealing, $50^{\circ} \mathrm{C}$ for $60 \mathrm{~min}$ for extension, followed by heat inactivation of the enzyme at $85^{\circ} \mathrm{C}$ for $5 \mathrm{~min}$. Reactions without Reverse transcriptase served as controls. After termination of cDNA synthesis, each RT reactions were diluted with nuclease-free water to a final volume of $50 \mu \mathrm{l}$ and stored at $-80^{\circ} \mathrm{C}$ till further use.

\section{Primer designing and validation}

Oligonucleotide primers for qRT-PCR analysis were designed from Bubalus bubalis complete mRNA sequence of GDF-9 (GenBank: FJ529501.2), BMP-15 (GenBank: EF375880.1) and GAPDH (GenBank: GU324291.1). Oligo Analyzer (1.1.2 Version) software was used to determine the Tm, GC per cent, primer loops, primer dimers and primer-primer compatibility. The FastPCR Professional (6.2.45 beta 4 version) has been used for Real time PCR primer designing and the oligonucleotide primers were synthesized from SigmaAldrich (USA). The designed primers were optimized prior to quantification experiments using polymerase chain reaction. For these genes, the expected sizes of the products were confirmed by gel electrophoresis on a $2 \%$ agarose gel. The primer sequences, expected fragment size of amplified products and genbank accession numbers are shown in Table 1.

\section{Real-time polymerase chain reaction}

Real-time PCR was performed to quantify the mRNA transcripts of GDF-9, BMP-15 in oocytes and cumulus cells using SYBR Green JumpStart Taq ReadyMix kit from Sigma-Aldrich, USA. Each cDNA sample was analysed in duplicate using real-time thermal cycler (Applied Biosystems, USA, ABI 7500). A non template control (NTC) was prepared using DEPC water without cDNA. Reactions were performed in $20 \mu \mathrm{l}$ volumes and loaded in the real-time qPCR 96-well plate $(10 \mu \mathrm{l} /$ well $)$ and the plate was centrifuged in cooling $\left(4^{\circ} \mathrm{C}\right)$ plate at
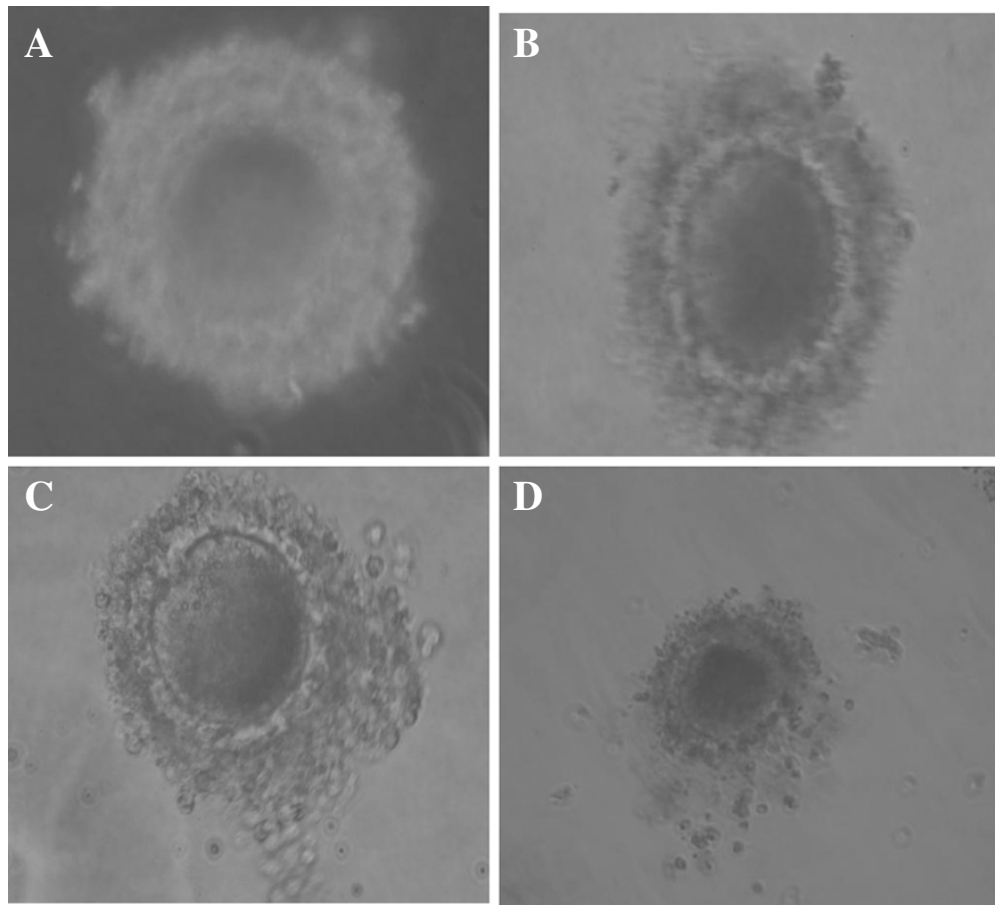

Figure 1 Morphological changes of buffalo COCs during IVM. COCs morphology observed under the microscope for: (A) 0 h, (B) 6 h, (C) 12 h, (D) $24 \mathrm{~h}$. During $12 \mathrm{~h}$ (C) and $24 \mathrm{~h}$ (D) of maturation, the outermost layers of the cumulus cells become round and glistening. 
$560 \mathrm{rpm}$ for $2 \mathrm{~min}$ to remove the air bubbles and kept for reaction in real time thermal cycler.

The PCR cyclic conditions were $95^{\circ} \mathrm{C}$ for $10 \mathrm{~min}$ followed by 40 cycles of denaturing at $95^{\circ} \mathrm{C}$ for 15 seconds and then annealing $\left(60^{\circ} \mathrm{C}\right.$ for GDF- $9,56^{\circ} \mathrm{C}$ for BMP- 15 , $58^{\circ} \mathrm{C}$ for $\mathrm{GAPDH}$ ) for $1 \mathrm{~min}$. The standard curve was obtained for GAPDH, GDF9 and BMP15 genes using 10fold dilutions of the sample and resultant slope of the curve was utilized for the calculation of the quantitative expression of both the target genes. The $\mathrm{Ct}$ values were recorded for both the target (GDF-9, BMP-15) and endogenous control genes (GAPDH). The data were accepted only if the NTC had no amplification.

\section{Interpretation of qRT-PCR}

Data were quantified using the method of relative quantification in qPCR (Pfaffl 2001). The threshold cycle value of reference gene was used to normalize the target gene signals in each sample. The amount of target transcripts relative to the calibrator was calculated by subtracting the $\mathrm{Ct}$ value of sample reference gene from the $\mathrm{Ct}$ value of the sample target gene. All samples were run in duplicate and the mean value of each duplicate was used for all further calculations. The $40-\Delta \mathrm{Ct}$ value gives the relative quantification of the transcripts.

\section{Statistical analysis}

Statistical analysis of the data was done as per the standard procedures of Snedecor and Cochran (1994). The gene expression status of all the genes analyzed was subjected to ANOVA using a computer-aided statistical software package SPSS 16.0 for windows. All the results are expressed as the mean $\pm \mathrm{SE}$ and statistical significance was accepted for $\mathrm{P}<0.05$.

\section{Results}

\section{In vitro maturation of buffalo oocytes and cumulus} expansion

Total of 692 culturable grade oocytes were collected in a batch of experiments and 20-25 oocytes were cultured in $100 \mu \mathrm{l}$ medium at each time-point to observe the progress of IVM. The COCs morphological changes were found at different time periods of culture (Figure 1). Maturation is assessed based on cumulus expansion and polarbody extrusion. Cumulus expansion was markedly increased at $12 \mathrm{~h}$ after IVM cultivation and continuously increased up to $24 \mathrm{~h}$. When preparing samples for expression analysis at different maturation stages, special attention was paid to selecting COCs with a uniform ooplasm and appropriate cumulus expansion to ensure an accurate status of oocytes and cumulus cells.

\section{Relative expression of GDF9 and BMP15 in buffalo oocytes during IVM}

The mRNA expression of GDF9 and BMP15 in oocytes during different hours of IVM showed differential changes (Figure 2A). Specifically, the RA of GDF9 mRNA gradually declined throughout the time period upto $24 \mathrm{~h}$ of maturation and showed significant $(\mathrm{P}<0.05)$ variation in the RA of GDF9 transcripts in cumulus free oocytes at between $0 \mathrm{~h}$ and $24 \mathrm{~h}$ of maturation. A significant $(\mathrm{P}<0.05)$ variation in the RA of $B M P 15$ transcript was observed in cumulus free oocytes of different maturation times. It increased between $6 \mathrm{~h}$ and $12 \mathrm{~h}$ of maturation and reduced between $12 \mathrm{~h}$ and $24 \mathrm{~h}$.

\section{Relative expression of GDF9 and BMP15 in buffalo cumulus cells during IVM}

The differential expression pattern of GDF9 and BMP15 mRNA transcripts in cumulus cells during different hours of IVM were presented in Figure 2B. The RA of GDF9 remained stable upto $12 \mathrm{~h}$ of maturation, but decreased significantly at $24 \mathrm{~h}$ of maturation. However,

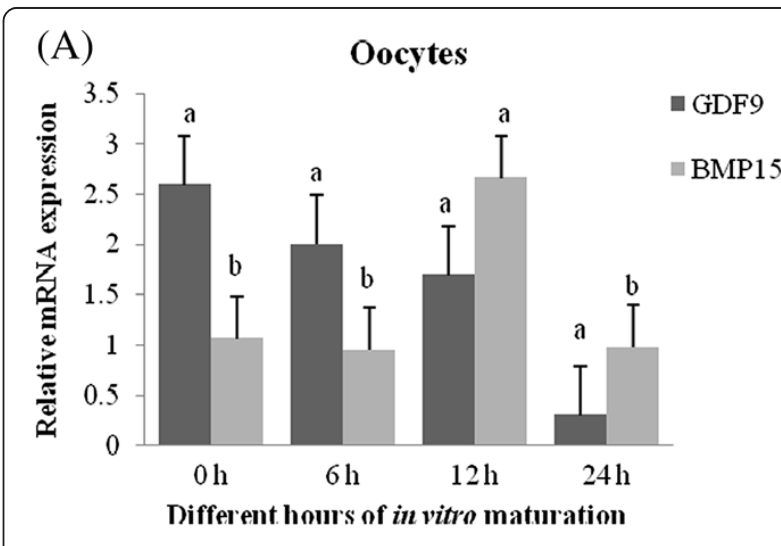

(B)

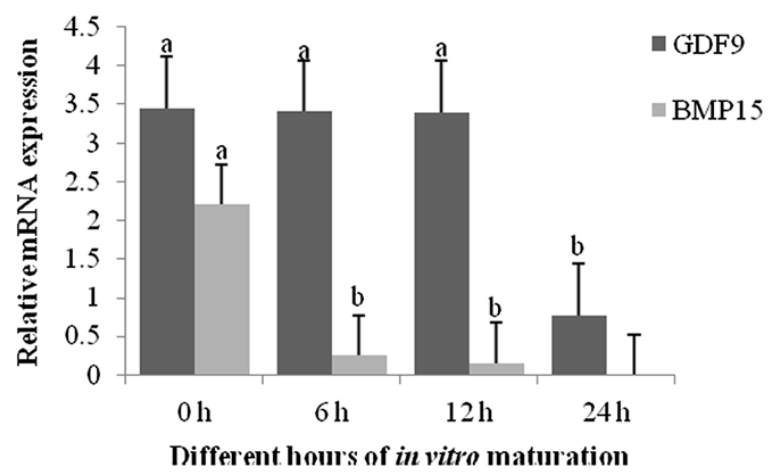

Figure 2 Relative expression of GDF9 and BMP15 in buffalo COCs during IVM. (A) Relative expression of GDF9 and BMP15 mRNA transcripts from oocytes. (B) Relative expression of GDF9 and BMP15 mRNA transcripts from cumulus cells. Data are presented as (mean $\pm \mathrm{SE}$ ). For each gene (GDF9 or BMP15), bars with different superscripts show significant difference $(P<0.05)$. 
$B M P 15$ showed a significant reduction in the RA between $0 \mathrm{~h}$ and $6 \mathrm{~h}$, stayed stable upto $12 \mathrm{~h}$ and become undetectable at $24 \mathrm{~h}$ of maturation.

\section{Discussion}

Ovarian folliculogenesis is a complex process depends upon numerous growth factors that regulate the growth and differentiation of oocytes, granulosa cells and theca cells. Oocyte-secreted GDF9 and BMP15 play essential roles during follicle maturation through actions on granulosa cells. GDF9 and BMP15 expression are less well characterized especially during IVM of COCs. Oocyte maturation is one of the important stages for the successful production of embryos in vitro. Moreover, it is well known that oocyte developmental potential is a reflection of proper maturation. So understanding the molecular mechanisms regulated during maturation is of great importance to optimize the IVM conditions. Since GDF9 and BMP15 are considered as important oocyte maturation factors during folliculogenesis (Gilchrist et al. 2004), this study investigated the potential relationship between GDF9 and BMP15 mRNA expression from in vitro matured oocytes and cumulus cells during the course of in vitro maturation.

In the present study significant difference in the RA of GDF9 transcripts in cumulus free oocytes, which showed gradual decline during IVM between $0 \mathrm{~h}$ and $24 \mathrm{~h}$ of maturation. This is in agreement with earlier findings that suggested the GDF9 expression to remain stable in oocyte during IVM (Prochazka et al. 2004), yet showed gradual decline during oocyte maturation (Li et al. 2008). Zhu et al. (2008) studied the temporal and spatial expression patterns of GDF9 gene in porcine COCs throughout in vitro maturation and reported that GDF9 highly transcribed in oocytes from fresh COCs, whereas expression was gradually decreased during IVM. Relative abundance of BMP15 from denuded oocytes during different hours of IVM increased significantly $(\mathrm{P}<0.05)$ between $6 \mathrm{~h}$ and $12 \mathrm{~h}$ and decreased again between $12 \mathrm{~h}$ and 24 . This increase in BMP15 transcript may be correlated with the cumulus expansion after $12 \mathrm{~h}$ of maturation in vitro. Similar to our finding, Li et al. (2008) observed a specific increase in porcine BMP15 transcript at $18 \mathrm{~h}$ of cumulus expansion during maturation. Zhu et al. (2008) reported that BMP15 was highly transcribed in oocytes from fresh COCs and the expression gradually declined during IVM.

It was also found that GDF9 RA in cumulus cells remained stable during IVM upto $12 \mathrm{~h}$ of maturation and decreased significantly between 12 and $24 \mathrm{~h}$ of maturation. This is in accordance with earlier studies, where RA of GDF9 mRNA was remained stable during the first $16 \mathrm{~h}$ of culture and significantly reduced during later stages of culture period in cumulus cells (Prochazka et al. 2004). This drastic change in the expression pattern of GDF9 during later stages of IVM could specify any probable role of this gene in selection of dominant follicle, which warrants further investigation. Whereas, BMP15 transcript was significantly reduced between $0 \mathrm{~h}$ and $6 \mathrm{~h}$, stayed stable upto $12 \mathrm{~h}$ and undetectable at $24 \mathrm{~h}$ of maturation. Likewise, Zhu et al. (2008) reported undetectable BMP15 expression pattern in cumulus cells during maturation. The absence of RA might be related to the degradation of transcripts after maturation of oocytes.

\section{Conclusion}

To conclude, during maturation of COCs in vitro, GDF9 mRNA showed significant reduction between $0 \mathrm{~h}$ and $24 \mathrm{~h}$ of maturation in oocytes. On the other hand, the RA of $B M P 15$ varied significantly $(\mathrm{P}<0.05)$ during IVM; It showed gradual increase between $6 \mathrm{~h}$ and $12 \mathrm{~h}$ and decreased again between $12 \mathrm{~h}$ and 24 . However in cumulus cells, GDF9 remained stable during IVM upto $12 \mathrm{~h}$ of maturation and decreased significantly between $12 \mathrm{~h}$ and $24 \mathrm{~h}$ of maturation. In case of $B M P 15$ significant reduction was observed between $0 \mathrm{~h}$ and $6 \mathrm{~h}$, stayed stable upto $12 \mathrm{~h}$ and become undetectable at $24 \mathrm{~h}$ of maturation. In future, further characterization of these genes from in vivo matured buffalo COCs will help in better understanding of the GDF9 and $B M P 15$ role in oocyte maturation of this species.

\section{Abbreviations}

GDF9: Growth differentiation factor9; BMP15: Bone morphogenetic protein15; mRNA: Messenger Ribonucleic acid; COCs: Cumulus-oocyte complexes; IVM: In vitro maturation; qRT-PCR: Quantitative real-time PCR; RA: Relative abundance.

\section{Competing interests}

The authors declare that they have no competing interests.

\section{Authors' contributions}

MK carried out the in vitro maturation and real time experiments, participated in data analysis and drafted the manuscript. ES participated in manuscript correction and helped in statistical analysis of data and VK participated in realtime data analysis. All the authors read and approved the final manuscript.

\section{Acknowledgement}

The authors are thankful to the Dean, Madras Veterinary College and Director of Research, TANUVAS for the facilities provided to carry out the research.

\section{Author details}

'Department of Veterinary Physiology, Laboratory of Reproductive Physiology, Madras Veterinary College, Chennai-600 007, TANUVAS, Tamil Nadu, India. ${ }^{2}$ Department of Veterinary Physiology and Biochemistry, Veterinary College and Research Institute, Tirunelveli- 627 001, TANUVAS, Tamil Nadu, India. ${ }^{3}$ Department of Animal Biotechnology, Madras Veterinary College, Chennai-600 007, TANUVAS, Tamil Nadu, India.

Received: 2 March 2013 Accepted: 3 May 2013

Published: 6 May 2013

\section{References}

Caixeta ES, Ripamonte P, Franco MM, Junior JB, Dode MAN (2009) Effect of follicle size on mRNA expression in cumulus cells and oocytes of Bos indicus: an approach to identify marker genes for developmental competence. Reprod Fertil Dev 21:655-664 
Campbell BK (2009) The endocrine and local control of ovarian follicle development in the ewe. Anim Reprod 6:159-171

Dube JL, Wang P, Elvin J, Lyons KM, Celeste AJ, Matzuk MM (1998) The bone morphogenetic protein-15 gene is X-Linked and expressed in oocytes. Mol Endocrinol 12:1809-1817

Gilchrist RB, Ritter LJ, Armstrong DT (2004) Oocyte-somatic cell interactions during follicle development in mammals. Anim Reprod Sci 82-83:431-446

Gode F, Gulekli B, Dogan E, Korhan P, Dogan S, Bige O, Cimrin D, Atabey N (2011) Influence of follicular fluid GDF9 and BMP15 on embryo quality. Fertil Steril 95:2274-2278

Hreinsson J, Scott J, Rasmussen C, Swahn M, Hsueh A, Hovatta O (2002) Growth differentiation factor-9 promotes the growth, development, and survival of human ovarian follicles in organ culture. J Clin Endocrinol Metab 87(1):316-321

Kobayashi K, Yamashita S, Hoshi H (1994) Influence of EGF and TGF-a on in vitro maturation of cumulus cell enclosed bovine oocytes in a defined medium. Reprod Fertil 100:439-446

Laitinen M, Vuojolainen K, Jaatinen R, Ketola I, Aaltonen J, Lehtonen E, Heikinheimo M, Ritvos O (1998) A novel growth differentiation factor-9 (GDF9) related factor is co-expressed with GDF-9 in mouse oocytes during folliculogenesis. Mech Dev 78:135-140

Li HK, Kuo TK, Yang HS, Chen LR, Li SSL, Huang HW (2008) Differential gene expression of bone morphogenetic protein-15 and growth differentiation factor-9 during in vitro maturation of porcine oocytes and early embryos. Anim Reprod Sci 103:312-322

Lonergan P, Gutierrez-Adan A, Rizos D, Pintado B, de la Fuente J, Boland MP (2003) Relative messenger RNA abundance in bovine oocytes collected in vitro or in vivo before and $20 \mathrm{hr}$ after the pre-ovulatory luteinizing hormone surge. Mol Reprod Dev 66:297-305

Moore RK, Erickson GF, Shimasaki S (2004) Are BMP-15 and GDF-9 primary determinants of ovulation quota in mammals. Trends Endocrinol Metab 15:356-361

Nandi S, Chauhan MS, Palta P (1998) Influence of cumulus cells and sperm concentration on cleavage rate and subsequent embryonic development of buffalo (Bubalus bubalis) oocytes matured and fertilized in vitro. Theriogenology 50:1251-1262

Pfaffl MW (2001) A new mathematical model for relative quantification in realtime RT-PCR. Nucleic Acids Res 29:e45

Prochazka R, Nemcova L, Nagyova E, Kanka J (2004) Expression of growth differentiation factor 9 messenger RNA in porcine growing and preovulatory ovarian follicles. Biol Reprod 71:1290-1295

Snedecor GW, Cochran WG (1994) Statistical methods, 8th edn. lowa State Univeristy Press, USA

Somfai T, Imai K, Kaneda M, Akagi S, Watanabe S, Haraguchi S, Mizutani E, DangNguyen TQ, Inaba Y, Geshi M, Nagai T (2011) The effect of ovary storage and in vitro maturation on mRNA levels in bovine oocytes; a possible impact of maternal ATP1A1 on blastocyst development in slaughterhouse-derived oocytes. J Reprod Dev 57:723-730

Watson AJ (2007) Oocyte cytoplasmic maturation: a key mediator of oocyte and embryo developmental competence. J Anim Sci 85:E1-E3

Yan C, Wang P, DeMayo J, Elvin JA, Carino C, Prasad SV, Skinner SS, Dunbar BS, Dube JL, Celeste AJ, Matzuk MM (2001) Synergistic roles of bone morphogenetic protein 15 and growth differentiation factor 9 in ovarian function. Mol Endocrinol 15:854-866

Zhu G, Guo B, Pan D, Mu Y, Feng S (2008) Expression of bone morphogenetic proteins and receptors in porcine cumulus oocyte complexes during in vitro maturation. Anim Reprod Sci 104:275-283

Zicarelli L (1994) Management under different environmental condition. Buffalo Journal Suppl. 2:17-38

doi:10.1186/2193-1801-2-206

Cite this article as: Kathirvel et al: Differential expression dynamics of Growth differentiation factor9 (GDF9) and Bone morphogenetic factor 15 (BMP15) mRNA transcripts during in vitro maturation of buffalo (Bubalus bubalis) cumulus-oocyte complexes. SpringerPlus 2013 2:206.

\section{Submit your manuscript to a SpringerOpen ${ }^{\odot}$ journal and benefit from:}

- Convenient online submission

- Rigorous peer review

- Immediate publication on acceptance

- Open access: articles freely available online

- High visibility within the field

- Retaining the copyright to your article

Submit your next manuscript at $\gg$ springeropen.com 